\title{
Salmonella enterica serovar Miami Possessing Both Virulence and Extended-Spectrum $\beta$-Lactamase Resistant Genes Isolated from Diarrhoeic Piglets of North East India (Mizoram)
}

\author{
Hosterson Kylla*, Tapan Kumar Dutta, Parimal Roychoudhury and \\ Prasant Kumar Subudhi
}
Department of Veterinary Microbiology, Central Agricultural University, Aizawl, Mizoram 796 014, India

*Corresponding author

\section{A B S T R A C T}

\section{Keywords}

Piglets, Diarrhoea, Salmonella Miami, PCR, Virulence, Antimicrobial drug resistance

Article Info

Accepted:

12 December 2017

Available Online:

10 January 2018
The present study report findings of an acute gastroenteritis outbreak in an unorganized pig farm in the tribal area of North East India (Mizoram). Faecal samples were collected from 12 pigs including 2 severely diarrhoeic piglets. A total of $25 \mathrm{E}$. coli were isolated, all of which were found to be negative for any putative virulence genes of STEC, ETEC, EHEC and EPEC pathotypes. However, no samples were found to be positive for Clostridium spp, viral (Rotavirus, Picobirna virus) and parasitic pathogens (eggs or larvae) under the study. Salmonella isolates $(\mathrm{n}=2)$ were isolated and confirmed as Salmonella enterica serovar Miami (9,12:a:1,5).PCR amplification of the genes in study showed present of enterotoxin (stn), invasive (invA) as well as ESBL bla $a_{\mathrm{TEM}-1}$ and $b l a_{\mathrm{CMY}-2}$ genes. Analysis of the strains by RAPD-PCR indicates that the strains were genetically different from other Salmonellae. The resistance trait from the isolates could not be transferred to the recipient host by the conjugation method. The isolated Salmonella strains were found to be multi drug resistant (MDR) strains. The present study report the isolation of Salmonella Miami strains possessing both virulence and ESBL genes, from severely diarrhoeic piglets in the tribal area of North East India (Mizoram).

\section{Introduction}

Salmonellosis is one of the major causes of acute gastroenteritis around the world and there are more than 2579 serovars of Salmonella that has been recorded across the globe (World Health Organization, 2007). Among the serovars, most commonly isolated from human are $S$. typhimurium and $S$. Enteritidis, whereas, most common serovars of animals origin are $S$. typhimurium and $S$.
Newport (CDC, 2006). Salmonella spp. are usually susceptible to many antimicrobial agents especially to the third generation cephalosporins such as cefotaxime, ceftriaxone and ceftazidime but a recent increase in the rates of resistance to these drugs is of serious concern globally particularly in developing countries. The present investigation reports the isolation of rare Salmonella strains possessing both virulence and ESBL genes, from severe 
diarrhoeic piglets of an unorganized farm in the tribal area of North East India (Mizoram).

\section{Materials and Methods}

\section{Collection of fecal samples}

The fecal samples were collected from pigs from an outbreak of acute gastroenteritis in two unorganized pig farms of Mizoram, India during 2014. Samples $(n=12)$ were collected from all the animals including 2 severely diarrhoeic piglets, and transported to laboratory under cold chain.

\section{Bacteriological screening of clinical specimens}

All the samples were processed for isolation and identification of possible enteric bacteria including E. coli, Salmonella and Clostridium spp.as per the method described by Ewing (1986) and also for detection of enteric viruses, including Rotavirus and Picobirna virus by RNA-PAGE and RT-PCR. Samples were also examined for the presence of parasitic eggs and larvae by standard floatation technique.

\section{Screening of samples for parasites}

All the faecal samples were tested for presence of common parasitic eggs by standard floatation technique.

\section{Detection of selected viral pathogens}

The faecal samples were screened for the presence of Rotavirus and Picobirna virus by RNA-PAGE analysis following standard protocol. In brief, samples were diluted in phosphate buffered saline ( $\mathrm{pH} 7.4$ ) to prepare a $10 \%(\mathrm{w} / \mathrm{v})$ faecal suspension. Clarified supernatant was collected and processed for RNA extraction using Trizol method (WHO, 2009). The extracted RNA was subjected to
RNA-PAGE followed by silver staining as per the standard procedure (Laemmli, 1970; Herring et al., 1982). Rotavirus and Picobirna virus was also detected by reverse transcription-PCR (RT-PCR). Detection of Rotavirus group $\mathrm{A}$ and $\mathrm{C}$ was performed by targeting VP7 gene (designed primers) and VP6 gene (Gabbay et al., 2008), respectively. For detection of Picobirna virus genogroup I (Rosen et al., 2000) and genogroup II specific primers (Smits et al., 2011) were used.

\section{Molecular characterization of the isolates}

DNA lysate for PCR analysis was prepared by standard boiling and snap chilling method. Detection of putative virulence genes of EPEC (eaeA), STEC (stx $\left.1, s t x_{2}\right)$, EHEC (hlyA) was evaluated by multiplex PCR (Paton and Paton 1998) and ETEC (LT and ST) by Phipps et al., (1995). Salmonella isolates was subjected to analysis by specific PCR for presence of putative virulence genes stn (Prager et al., 1995), invA (Galan et al., 1992), pef (Rahman et al.,2000) and ESBL resistant genes bla $a_{\mathrm{TEM}}$ (Weill et al., 2004), bla $a_{\mathrm{SHV}}$ (Schjorring et al., 2008), bla $a_{\mathrm{CMY}-2}$ and bla $a_{\mathrm{CTX}}$ (Perez and Hanson, 2002)as depicted in Table 1. PCR amplification was performed in a Master cycler gradient (Eppendorf, Germany) with PCR mixture in a thin walled $0.2 \mathrm{ml}$ PCR tube included a final volume of $25 \mu \mathrm{l}$ containing 10X Dream taq buffer with $\mathrm{MgCl}_{2}(20 \mathrm{mM})$, dNTP mix (25 mM each), $5 \mathrm{U} / \mu \mathrm{l}$ Taq DNA polymerase, $1 \mu \mathrm{l}(20 \mathrm{pmol})$ each of forward and reverse primer, $4 \mu \mathrm{l}$ of template DNA and nuclease free water to make up the volume $25 \mu 1$.Amplified products were separated by $1 \%$ agarose gel in $1 \mathrm{X}$ Tris-borate-EDTA buffer by electrophoresis and stained with ethidium bromide $(0.5 \mu \mathrm{g} / \mathrm{ml})$. Standard molecular size marker (100 bp DNA ladder) was included in each gel. DNA fragments were observed by ultraviolet trans illuminator and photographed in a gel documentation system (Alpha Imager, Germany). 
Randomly amplified polymorphic DNA-PCR for molecular typing of the isolates was performed using a single primer (5'AAGAGCCCGT-3') according to Akopyanz et al., 1992.Conjugation was carried out using the method of Hasman et al., (2005). A plasmid-free, amoxycillin-susceptible, but nalidixic acid and rifampin-resistant Salmonella enterica serovar Typhimurium isolate was the recipient for mating experiments. Trans conjugants were selected on LB agar plates containing ampicillin $(32 \mu \mathrm{g} / \mathrm{ml})$ and nalidixic acid $(50 \mu \mathrm{g} / \mathrm{ml})$.

\section{Serotyping of Salmonella isolates}

The Salmonella isolates were serotyped on the basis of their somatic antigen at National Salmonella and Escherichia Centre, Central Research Institute, Kasauli, Himachal Pradesh (India).

\section{Antimicrobial sensitivity assay}

The Salmonella isolates were subjected to in vitro drug sensitivity test by disc diffusion method against 15 commonly used antibiotics (Hi-Media): ampicillin (10mcg), amoxycillin (30 mcg), aztreonam (30mcg), cefalexin (30mcg), ceftazidime (30 mcg), cefixime (5mcg), ceftriaxone (30mcg), cefotaxime (30mcg), ciprofloxacin $(5 \mathrm{mcg})$, enrofloxacin (10mcg), gentamicin (10mcg), imipenam (10mcg), nalidixic acid (30mcg), piperacillin (10mcg) and streptomycin (10mcg). Antimicrobial susceptibility test was done on Mueller-Hinton agar (Hi-Media) plate as per criteria of Clinical Laboratory Standard Institute (CLSI, 2013). Zones of inhibition were measured using zone size interpretative chart furnished by the manufacturer.

\section{Results and Discussion}

No clostridial organisms were detected by anaerobic culture. Salmonella isolates $(\mathrm{n}=2)$ were recovered from 2 severely diarrhoeic piglets based on standard bacteriological and biochemical tests. All the E. coli $(\mathrm{n}=25)$ isolated from the samples were found to be negative for any putative virulence genes $e a e A, s t x_{1}, s t x_{2}, h l y A, l a$ and $s t$ genes by PCR. On laboratory examination as stated earlier, no samples were found to contain parasitic eggs or larvae. Rotavirus and/or Picobirna virus also could not be detected by either RNAPAGE or by RT-PCR.

Both the two Salmonella isolates were serotyped/assigned as Salmonella enterica serovar Miami (9, 12: a: 1, 5).

PCR amplification of the genes in study revealed the strains yielded a 617 bp product in the enterotoxin (stn) gene segment and presence of invasive (invA) gene which yielded amplicon size 941 bp. Both the isolates were found negative for $p e f$ gene.

Furthermore, of the four ESBL genes tested by $\mathrm{PCR}$, the isolates were found to harboured drug resistance ESBL - bla $a_{\mathrm{TEM}-1}(1080 \mathrm{bp})$ and $b l a_{\mathrm{CMY}-2}(462 \mathrm{bp})$ genes (Fig. 1).

Analysis of $S$. Miami strains of the present study by RAPD-PCR revealed similar bands between them, but when comparing with other Salmonella spp. revealed unidentical banding patterns which indicate that the strains were genetically different from other Salmonellae. The resistance trait from the isolates could not be transferred to the recipient host by conjugation method.

The isolated Salmonella strains were found to be multi drug resistant (MDR) strains revealing resistant to ampicillin, amoxycillin, cephalexin, enrofloxacin, piperacillin, cefixime, cefotaxime and showing sensitivity to imipenem, ceftriaxone, aztreonam, streptomycin, nalidixic acid, gentamicin, ciprofloxacin and ceftazidime. 
Table.1 Details of the oligonucleotide primers used in the present study

\begin{tabular}{|c|c|c|c|c|}
\hline Primer & Sequences $\left(5^{\prime}-3^{\prime}\right)$ & $\begin{array}{l}\text { Annealing } \\
\text { temp. }\end{array}$ & $\begin{array}{l}\text { Amplicon } \\
\text { size (bp) }\end{array}$ & References \\
\hline stn & $\begin{array}{l}\text { (F) TTGTGTCGCTATCACTGGCAACC } \\
\text { (R) ATTCGTAACCCGCTCTCGTCC }\end{array}$ & $61{ }^{0} \mathrm{C}$ & 617 & $\begin{array}{l}\text { Prager et al., } \\
1995\end{array}$ \\
\hline$\overline{i n v A}$ & $\begin{array}{l}\text { (F) ACCACGCTCTTTCGTCTGG } \\
\text { (R) GAACTGACTACGTAGACGCTC }\end{array}$ & $60^{\circ} \mathrm{C}$ & 941 & $\begin{array}{l}\text { Galan et al., } \\
1992\end{array}$ \\
\hline pef & $\begin{array}{l}\text { (F) TGTTTCCGGGCTTGTGCT } \\
\text { (R) CAGGGCATTTGCTGATTCTTCC }\end{array}$ & $57^{0} \mathrm{C}$ & 700 & $\begin{array}{l}\text { Rahman et al., } \\
2000\end{array}$ \\
\hline bla $_{\mathrm{TEM}}$ & $\begin{array}{l}\text { (F) ATAAAATTCTTGAAGACGAAA } \\
\text { (R) GACAGTTACCAATGCTTAATC }\end{array}$ & $53^{0} \mathrm{C}$ & 1080 & $\begin{array}{l}\text { Weill et al., } \\
\quad 2004\end{array}$ \\
\hline bla $_{\mathrm{SHV}}$ & $\begin{array}{c}\text { (F) CGCCTGTGTATTAATCAGTGAGGCAC } \\
\text { (R) TTGCCAGTGCTCGATCAGCG }\end{array}$ & $60^{\circ} \mathrm{C}$ & 842 & $\begin{array}{l}\text { Schjorring et } \\
\text { al., } 2008\end{array}$ \\
\hline $\begin{array}{l}\text { bla }_{\mathrm{CMY}} \\
\quad 2\end{array}$ & $\begin{array}{l}\text { (F) TGGCCAAGAACTGACAGGCAAA } \\
\text { (R) TTTCTCCTGAACGTGGCTGGC }\end{array}$ & $60^{\circ} \mathrm{C}$ & 462 & $\begin{array}{c}\text { Perez and } \\
\text { Hanson, } 2002\end{array}$ \\
\hline $\begin{array}{c}\text { bla }_{\mathrm{CTX}}^{-} \\
\mathrm{M}\end{array}$ & $\begin{array}{l}\text { (F) CAATGTGCAGCACCAGTAA } \\
\text { (R) CGCGATATCGTTGGTGGTG }\end{array}$ & $58^{0} \mathrm{C}$ & 540 & $\begin{array}{c}\text { Perez and } \\
\text { Hanson, } 2002\end{array}$ \\
\hline
\end{tabular}

Fig.1 Salmonella Miami positive for $\operatorname{stn}(617 \mathrm{bp})$, invA (941bp), bla $a_{T E M-1}(1080 \mathrm{bp})$, bla $_{C M Y-2}$ (462bp) genes

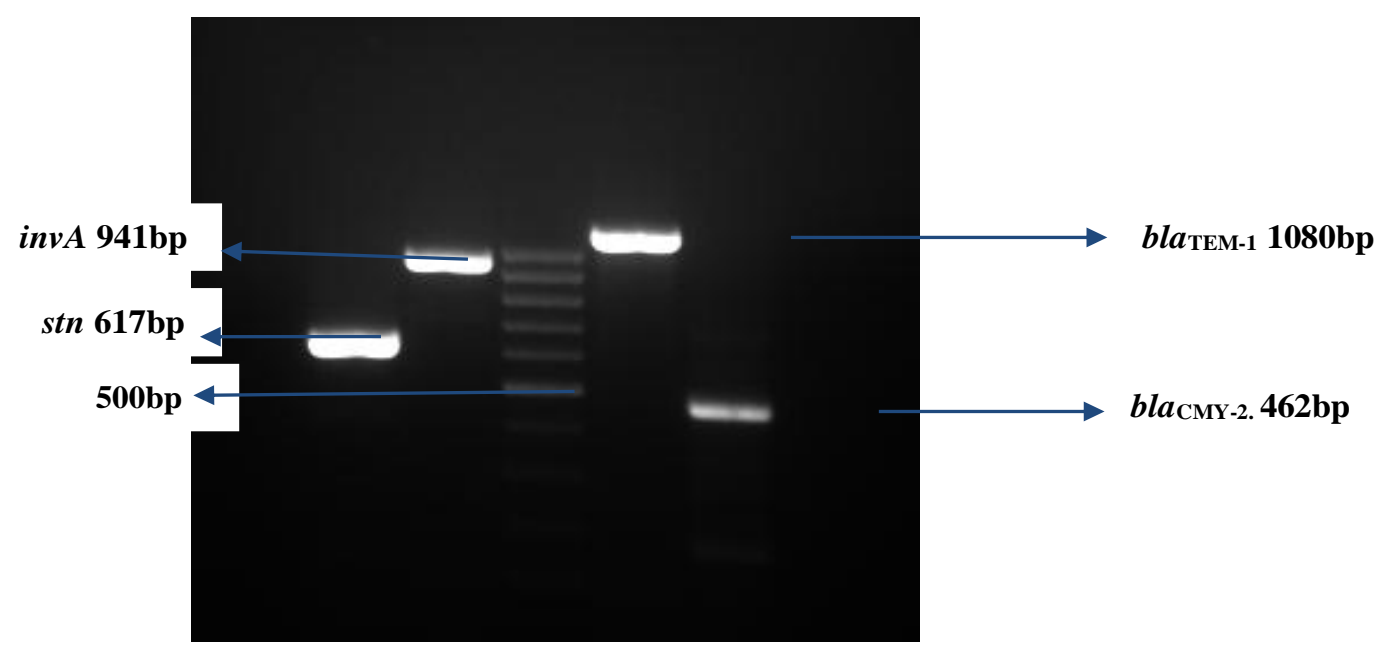

Resistance to cephalosporin drugs and detection of such resistance genes from resistant Salmonella isolates in food animals are to be associated with human disease (Blanc et al., 2006).

The two putative virulence genes of Salmonella spp. viz., Enterotoxin (stn) and invasion (invA) are extensively present in Salmonella spp. irrespective of various serovars; and many workers considered molecular characterization of invA gene as a standard for detection of Salmonella genus (Prager et al., 1995; Rahman, 1999; Malorny et al., 2003). Salmonella Typhimurium is most commonly associated with enteric infections in man and animals (Rahman, 2002; Murugkar et al., 2005). In another report, S. enteritidis, S. typhimurium and $S$. typhi are the main serovars consisted of $76.1 \%$ of all isolates reported from 104 
countries (Herikstad et al., 2002). Isolation of Salmonella Miami is of significant as this serovar has been rarely reported in India and this is the first published report of the involvement of Salmonella Miami in piglet diarrhoea in India.

Detection of Salmonella strains with simultaneous combination of virulence and ESBL resistance genes mentioned in present research article is a cause of public health concern, and it indicate the nature of continuous selective pressure which promote combinations of virulent and resistant strains. Hence, regular monitoring for Salmonella spp. in food animals is very much necessary which must include adequate antimicrobial susceptibility testing and molecular characterization.

There are reports around the globe of Salmonella spp. possessing either virulence or ESBLs genes, but to the best of our knowledge, this is probably the first information in India or elsewhere of ESBL-producing Salmonella isolates possessing virulence genes belonging to Salmonella enterica serovar Miami (9, 12: a: 1 , 5).

\section{Acknowledgement}

The authors are thankful to the Institutional Biotech Hub, Department of Biotechnology, Government of India, DBT project on ADMaC and Dean, College of Veterinary Sciences and Animal Husbandry, Aizawl, Mizoram, India for providing all the facilities to conduct the present work.

\section{Competing Interests}

Authors have declared that no competing interests exist.

\section{References}

Akopyanz, N., Bukanov, N.O., Westblom, T.U., Kresovich, S. and Berg, D.E. 1992. DNA diversity among clinical isolates of
Helicobacter pylori detected by PCRbased RAPD fingerprinting. Nucleic Acids. Res, 20(19): 5137-5142.

Blanc, V., Mesa, R., Saco, M., Lavilla, S., Prats, G., Miro, E., Navarro, F., Cortes, P. and Llagostera, M. 2006. ESBL and plasmidic class $\mathrm{C}$ beta-lactamase-producing $E$. coli strains isolated from poultry, pig and rabbit farms. Vet. Microbiol, 118: 299304.

Centre for Disease Control and Prevention. 2006. Salmonella Surveillance: Annual Summary. Centre for Disease Control and Prevention Report. Atlanta, Ga.

Clinical Laboratory Standards Institute. 2013. Performance standards for antimicrobial susceptibility testing. Twenty third informational supplement. M100-S23. Wayne, USA.

Ewing, W.H. 1986. Edward and Ewing's Identification of Enterobacteriaceae, 4th edn. New York Elsevier, pp. 1-536.

Gabbay, Y.B., Borges, A.A., Oliveria, D.S., Linhares, A.C., Mascarenhas, J.D., Barardi, C.R., Simoes, C.M., Wang, Y., Glass, R.I., Jiang, B. 2008. Evidence for zoonotic transmission of group $\mathrm{C}$ rotaviruses among children in Belem, Brazil. J. Medical Virol, 80: 1666-1674.

Galan, J.E., Ginocchio, C. and Costeas, P. 1992. Molecular and functional characterization of the Salmonella gene invA: homology of invA to members of a new protein family. J. Bacteriol., 174: 4338-4349.

Hasman, H., Mevius, D., Veldman, K., Olesen, I. and Aarestrup, F.M. 2005. Betalactamases among extended-spectrum beta-lactamase (ESBL)-resistant Salmonella from poultry, poultry products and human patients in The Netherlands. $J$. Antimicrob. Chemother, 56:115-121.

Herikstad, H., Motarjemi, Y. and Tauxe, R.V. 2002. Salmonella surveillance: a global survey of public health serotyping. Epidemiol. Infect., 129: 1-8.

Herring, A.J., Inglis, N.F., Ojeh, C.K., Snodgrass, D.R., Menzies, J.D. 1982. Rapid diagnosis of rotavirus infection by direct detection of viral nucleic acid in 
silver-stained polyacrylamide gels. $J$. Clin. Microbiol., 16: 473-477.

Laemmli, U.K. 1970. Cleavage and structural proteins during the assembly of the head bacteriophage T4. Nature, 227: 680-685.

Malorny, B., Hoorfar, J., Bunge, $\mathrm{C}$ and Helmuth, R. 2003. Multicenter validation of the analytical accuracy of Salmonella PCR towards an international standard. Appl. Environ. Microbiol, 69: 290-296.

Murugkar, H.V., Rahman, H., Kumar, A. and Bhattacharya, D. 2005. Isolation, phage typing and antibiogram of Salmonella from man and animals in north eastern India. Ind. J. Med. Res, 122:237-242.

Paton, J.C., Paton, A.W. 1998. Pathogenesis and diagnosis of Shiga toxin-producing Escherichia coli infections. Clinical Microbiology Reviews, 11: 450-479.

Perez, F.J. and Hanson, N.D. 2002. Detection of Plasmid-Mediated AmpC $\beta$-Lactamase Genes in Clinical Isolates by using Multiplex PCR. J. Clin. Microbiol, 40.6:2153-2162.

Phipps, S.S., Mecca, J.J., Weiss, J.B. 1995. Multiplex PCR Assay and Simple Preparation Method for Stool Specimens Detect Enterotoxigenic Escherichia coli DNA during Course of Infection. J Clin Microbiol., 1054-1059.

Prager, R., Fruth, A. and Tschape, H. 1995. Salmonella enterotoxin (stn) gene is prevalent among strains of Salmonella enterica but not among Salmonella bongori and other enterobacteriaceae. FEMS Immunol. and Med. Microbiol, 12: 47-50.

Rahman, H. 1999. Prevalence of enterotoxin gene (stn) among different serovars of Salmonella. Ind. J. Med. Res, 110: 43-46.
Rahman, H. 2002. Some aspects of molecular epidemiology and characteristics of Salmonella typhimurium isolated from man and animals. Ind. J. Med. Res, 115: 108-112.

Rahman, H., Prager, R. and Tschape, H. 2000. Occurrence of sef and pef genes among different serovars of Salmonella. Ind. J. Med. Res, 111:40-42.

Rosen, B.I., Fang, Z.Y., Glass, R.I., Monroe, S.S. 2000. Cloning of human Picobirna virus genomic segments and development of RT-PCR detection assay. Virology, 277 (2): 316-329.

Schjorring, S., Struve, C., Krogfelt, K.A. 2008. Transfer of antimicrobial resistance plasmids from Klebsiella pneumoniae to Escherichia coli in the mouse intestine. $J$. Antimicrob. Chemother, 62: 1086-1093.

Smits, S.L., Poon, L.M.M., Van Leeuwen, M., Lau, P.N., Parera, H.K.K., Peiris, J.S.M., Simon, J.H., Osterhaus, A.D. 2011. Genogroup I and II Picobirna viruses in Respiratory Tracts of Pigs. Emerging Infectious Diseases, 17, (12): 2328-2330.

Weill, F.X., Demartin, M., Laetitia Fabre, L. and Grimont Patrick, A.D. 2004. Extended-spectrum-beta lactamase (TEM-52)-producing strains of Salmonella enterica of various serotypes isolated in France. J. Clin. Microbiol, 42:3359-3362.

World Health Organization. 2007. Antigenic Formulae of the Salmonella serovars: WHO Collaborating Centre for Reference and Research on Salmonella. 9th edn.

World Health Organization. 2009. Manual of rotavirus detection and characterization methods. Geneva, Switzerland.

\section{How to cite this article:}

Hosterson Kylla, Tapan Kumar Dutta, Parimal Roychoudhury and Prasant Kumar Subudhi. 2018. Salmonella enterica serovar Miami Possessing Both Virulence and Extended-Spectrum $\beta$ Lactamase Resistant Genes Isolated from Diarrhoeic Piglets of North East India (Mizoram). Int.J.Curr.Microbiol.App.Sci. 7(01): 1451-1456. doi: https://doi.org/10.20546/ijcmas.2018.701.176 